\title{
NON-RECOGNITION OF INTERNALLY GENERATED BRANDS: IMPLICATIONS FOR THE USEFULNESS OF FINANCIAL STATEMENTS
}

\author{
Pieter van Aardt van der Spuy* \\ Stellenbosch University \\ vanderspuy@sun.ac.za
}

Received: September 2014

Accepted: September 2015

\begin{abstract}
International Accounting Standard 38 (IAS38) prohibits the recognition of internally generated brands as assets. This article explores the implications of this prohibition for the usefulness of financial statements, focusing on the implications for note-disclosure. A theoretical doctrinal research approach is taken in which the literature on intangible assets and current accounting standards is examined and evaluated. The article highlights the information content relevant to unrecognised brand assets that is not currently disclosed to users of financial statements. Furthermore, the article argues and explains how this situation may compromise the usefulness of financial statements. Practitioners compiling financial statements may find the conclusions and recommendations useful in improving voluntary note-disclosure when a reporting entity owns significant unrecognised brand assets. The International Accounting Standards Board (IASB) may find the article useful in reviewing IAS38's mandatory note-disclosure requirements in order to improve the usefulness of financial statements.
\end{abstract}

Keywords

Internally generated brands, International Accounting Standards Board (IASB), The Conceptual Framework for Accounting, Trademarks, Asset recognition, Voluntary disclosure

*Mr P van Aardt van der Spuy is a lecturer in the School of Accountancy, University of Stellenbosch, South Africa. 


\section{INTRODUCTION AND BACKGROUND}

'What is essential is invisible to the eye' (De Saint-Exupéry, 2009:70). To what extent may the subtle indictment in this quote be directed at accountants, as far as internally generated brands are concerned? This investigation was precipitated by marketers' claims regarding 'brand-related information' that is hidden from financial statements (Sinclair \& Keller, 2014). Internally generated brands are not recognised as assets on the Statement of Financial Position (SFP). This prohibition may invariably exempt internally developed brands, in stark contrast to acquired brands, from informative and complementary note-disclosure. Drawing from De Saint-Exupéry's (2009) quote, this article investigates whether that which is truly essential regarding internally generated brands may in fact not be disclosed to users of financial statements. This investigation may serve to highlight the importance of extending the existing mandatory note-disclosure that is applicable to recognised brands to include unrecognised brands as well.

\section{PROBLEM STATEMENT}

The main objective of International Accounting Standards (IASs) is to provide useful information in the form of financial statements (IASB, 2014:A19, paragraph OB2). Users of financial statements use such information to inform a wide range of business decisions with regard to the reporting entity. These decisions include whether or not financial resources will be provided to organisations in the form of equity investments or loans (IASB, 2014:Al6 and IASB, 2014:A19, paragraph OB2). According to the IASB (2014:A22, paragraphs OB13-OB16), users of financial statements need information about a reporting entity's resources, liabilities as well as information that enables them to determine the variability, timing and uncertainty related to future cash flows. Arguably, this is also the type of information used in valuation models when equity-valuations are performed. The core objective of financial statements is not to show the value of a reporting entity, but rather to ensure that users of financial statements have the necessary information to utilise in valuations (IASB, 2014:A20, paragraph 0B7). It follows that information which actually exists, but which is not disclosed to users, may detrimentally affect the completeness or accuracy of valuations, and consequently reduce the purported usefulness of financial statements.

However, not all useful financial information can be recognised as components of financial statements according to the Conceptual Framework for Accounting. Information needs to be both relevant and a faithful representation of the events. The relevance of financial information is evaluated in terms of the ability of information to influence users' decisions (IASB, 2014:A26, paragraph $(C 6)$, while the faithfulness of information is evaluated with reference to the extent to which information content is complete, neutral and free from error (IASB, 2014:A26 paragraph QC12). Preparers of financial statements are furthermore implored to enhance these qualitative characteristics as much as possible (IASB, 2014:A30, paragraph QC33).

Although internally generated brands exhibit characteristics similar in all material aspects to acquired brands, asset recognition is entirely prohibited because they do not have a determinable cost or estimable value according to IAS38, paragraph 63 (IASB, 2014:A1337). This bigoted approach may appear contradictory to the spirit of the Conceptual Framework for Accounting, given its assertion that the use of estimates is considered inherent to, and inevitable in achieving the objectives of the financial reporting process (IASB, 2014:A40, paragraph 4.41). Contradictions like these may be responsible for creating confusion and may be part of the reason for criticism 
from other disciplines, including marketing, regarding the seemingly inconsistent application of accounting principles.

Despite the evolvement in marketers' ability to value brands, the requirements of IAS38 paragraph 76 seem to render these developments redundant as far as financial statements are concerned for the following two reasons (IASB, 2014:A1341). Firstly, the revaluation model excludes from its application the revaluation of intangible assets which have not previously been recognised at cost. Secondly, application of the revaluation concept is not permitted for intangible assets, because the fair value cannot be determined by reference to an active market.

Considering that internally generated brands seem to differ from their recognised counterparts only with regards to the existence of an identifiable cost, and given, furthermore, the significant economic monetary market values ascribed, as well as their strategic nature, this may indeed suggest an aberration. Despite the fact that financial statements can never entirely satisfy all the information needs of all users, it may seem as if the present accounting standards enable users to become aware of the existence of some assets, belatedly, only when they are sold to another party. The implications that this prevailing accounting issue have had in the past and still continue to have for the usefulness of financial statements may not yet be fully appreciated by accountants in practice, standard setters and accounting academics. Marketing academics Sinclair and Keller (2014) express the marketing discipline's pique with the accounting fraternity's impasse on the issue as follows:

an unacceptable dichotomy hides important information from investors and masks the full contribution brands make to enterprise wealth. Since 2001 there have been several attempts to update the standards that created that. However, these have never been seen as a priority and have been aborted before completion (Sinclair \& Keller, 2014:286).

The IASB's goal with accounting standards is to enable users of financial statements to make informed decisions. Given this goal, marketers' pleas for more information regarding unrecognised brands, as indicated above, cannot be ignored. These pleas from marketers may, however, be biased, possibly intended and construed as a pretext for the ultimate recognition of internally generated brands. Considering that financial statements also include associated notedisclosure, it seems as if the potential utility of the extension of note-disclosure's coverage of these brands has not yet been exploited as a possible solution. Conversely, the extent to which information content that is normally disclosable for acquired brands is not available with regard to unrecognised brands may in fact be tantamount to concealing information from investors.

A surfeit of literature exists that explores, debates and contrasts the numerous arguments and perspectives concerning the recognition of internally generated intangible assets on the SFP. Tollington (1998:180) and Fraser, Tarbert and Hong-Tee (2009) argue for a change in accounting standards to present brands more effectively. They concede, however, that the measuring aspect of brands poses problems, since there appears to be little consensus on appropriate valuation methods. Other studies convincingly construed IAS38's assertion as a fait accompli: that internally generated brands cannot be measured reliably (Barth, Clement, Foster \& Kaznik, 1998:1 and Sinclair \& Keller, 2014:286). A study by Wyatt (2002:83), however, refutes the concerns of prudent conservatives regarding the reliability of measurements, indicating that even this problem may in fact be surmountable.

Studies and arguments regarding the urgent need to recognise internally generated intangible assets abound. Lev (2003:19) contends that the usefulness of the information in financial statements is rapidly deteriorating and argues that stakeholders should demand a resolution of the issue as a matter of urgency. Various studies by eminent researchers convincingly support the 
warning, indicating how value-relevant financial information related to intangible assets is to the users of financial statements (Powell, 2003:806, Kohlbeck \& Warfield, 2007:23, Chalmers, Clinch \& Godfrey, 2008:238, Barth \& Clinch, 1998:201, Deng \& Lev, 1998, as reported in Powell, 2003:807).

The debate also extends to a range of opinions regarding the most appropriate solutions to the issue. Lev (2003:21) proposes immediate recognition of internally generated intangible assets at current market values, together with the restatement of past financial reports. He also invokes users' notoriously lacklustre response to standard setters' calls for constructive feedback during accounting standard amendment processes, and exhorts users to become more vigilant in influencing standard setters to introduce necessary changes. Furthermore, he suggests the development and application of intangible asset disclosure indexes which may be useful in guiding the preparers of financial statements to disclose important information content regarding unrecorded intangible assets through the note-disclosure which accompanies financial statements (Lev, 2003:21).

Given the remarkably convoluted and contentious nature of the issue, Wyatt and Abernethy (2008:95) propose, as a possible first step to resolve the issue, mandatory identification and separate reporting of expenses related to intangible assets. Furthermore, they also suggest recognition of internally generated intangible assets upon meeting certain conditions, such as the existence of legal property rights (Wyatt \& Abernethy, 2008:95).

Looking at the main viewpoints voiced above, one aspect seems to have been omitted from the discourse in the literature: the current implications for the usefulness of financial statements when unrecorded brands are exempted from the mandatory note-disclosure content that applies to recognised brands. The nature of the information gap presented by this situation might have significant consequences are the usefulness of financial statements. This article aims to contribute to the existing literature by investigating the possible implications for the usefulness of financial statements.

The next section discusses the objectives of this article and the research methodology used.

\section{OBJECTIVES AND RESEARCH METHODOLOGY}

\subsection{Research objective}

The primary objective of this article is to investigate the implications for the usefulness of financial statements when the note-disclosure requirements that are mandatorily imposed on recognised intangible assets are not also extended to cover unrecognised intangible assets. The scope is limited to internally generated brands as one class of unrecognised intangible assets.

\subsection{Research methodology}

Due to limited available literature that provides guidance for the composition of purely theoretical or conceptual accounting research papers, the author referred to the methodology for theoretical papers articulated by Hutchinson and Duncan (2012:101). This methodology was also used by Strauss and Willemse (2014) in a theoretical study on legal and taxation issues. The legal profession, legal academics and accounting academics often face rather similar issues, from a theoretical point of view. On the one hand, legal practitioners and legal academics observe how current legislation in a country is applied in practice or is interpreted by judges and advocates. 
Conversely, accounting academics observe the development and amendment of accounting standards and how preparers of financial statements interpret and apply the requirements of a chosen accounting framework and accounting standards in the preparation of financial statements. As part of an iterative process, both academic disciplines seek to identify problems or issues in the current application of legislation (accounting frameworks and accounting standards), striving to offer useful criticism and informed recommendations for improvements through an appropriate collaborative process.

It therefore seems appropriate, except for the necessary semantic changes, to use Hutchinson and Duncan's (2012) theoretical research methodology. They describe conceptual research as

research which provides a systematic exposition of the rules governing a particular legal category, analyses the relationships between rules, explains areas of difficulty and, perhaps, predicts future developments (Hutchinson \& Duncan, 2012).

Consequently, this research paper follows a qualitative, doctrinal approach through a purely theoretical and documentary analysis which is augmented and complemented with application of discussion and logical argumentation.

The article is structured into the following three parts. The first part provides a brief description of the strategic importance and unique nature of brands. To this end, reference was made to the relevant literature in the marketing domain. The purpose of this part is to provide the appropriate context and background for the interpretation of the arguments developed in the rest of the article. The second part identifies the specific note-disclosure requirements, contained in IAS38, that apply to recognised intangible assets, but from which internally generated brands are currently excluded. The author then discusses the implications for the usefulness of financial statements, as understood by the IASB as the developer of accounting standards. The third part considers the prospects for the IASB's encouragement regarding voluntary note-disclosure to ameliorate a paucity of information as far as internally generated brands are concerned. Since accounting standards often have close linkages and mutual references to one another, the arguments are also extended to include the implications for these standards, as and when IAS38 distinctly refers to other international accounting standards.

The arguments in the article are developed using deductive logic and include suitable reference to extant accounting knowledge and theory where applicable. South African Intellectual Property Law legislation, as the umbrella term used by legal academics for intangible assets such as brands, is also referred to, and is also incorporated into the arguments. Furthermore, to illuminate the nature of the implications, reference is made to an actual corporate event as an apt example of a company's past dealings with its brands. The intention with this example should not be interpreted as an attempt to extrapolate any arguments to general cases. Rather, reference to the example is useful to contextualise the plausibility of the arguments.

The article concludes with suggestions for practical improvements to the existing disclosure requirements contained in IAS38, to better meet the IASB's objective of providing useful information to users of financial statements. The next section discusses the strategic importance of brands.

\section{THE STRATEGIC IMPORTANCE OF BRANDS}

The increasing strategic importance of marketing brands and brand portfolio management to companies' sustained financial performance is considerable. This intangible resource has become 
one of the most effective commercial approaches used today in order to gain and maintain market share over competitors (Appuhami, 2007; Mizik \& Jacobson, 2008). Moreover, brands are arguably akin to licences to operate, or seen as being the bare minimum to remain successful in a competitive world in which many consumer products are increasingly at risk of being commoditised.

Brand names are now regarded as some companies' most important assets, as they yield competitive advantage and safeguard companies' future revenue streams (Aaker, 1991). The importance is mirrored by the fact that brands may account for more than $30 \%$ of the stock market value of companies in the S\&P 500 index (The Economist, 2014). Based on this notion, Crimmins (2000:44) points out that better brand portfolio management depends on the extent to which a brand's value is tracked and monitored in order to assess whether value is added to the brand or whether value is eroded from the brand. Regarding the contentious question of whether to sell a brand from the brand portfolio, he warns 'it asks us to acknowledge that when we trade away our ability to make a profit today, we have made a bad bargain' (Crimmins, 2000:144). Petty and Guthrie (2000:155) echo this view, contending that intellectual capital, which includes brands, will be instrumental in the determination of future enterprise values. They contend that boardrooms are increasingly acknowledging the strategic importance of intellectual capital as a unique source of much sought-after, but ever elusive competitive advantage.

Likewise, information concerning the existence of brands is also important for accurate business valuations. The existence of brand assets influences contemporaneous drivers of business valuations (Mizik \& Jacobson, 2009:1). This research provides strong evidence that the accuracy of the valuation of a company's equity can be improved significantly if information about the properties and characteristics of a firm's brand assets are incorporated directly into the valuation framework used. This was later vindicated empirically by Swartz and Swartz (1995:67), who found a statistically significant relationship between share prices and investment in intellectual capital.

From a legal perspective, brands (referred to as 'trademarks' in legal terms) are also regarded as adequate and valuable forms of security for lenders, the same as any other piece of property, plant and equipment normally encumbered when pledged as security for loans (Klopper, Pistorius, Rutherford, Tong, Van der Merwe \& Van der Spuy, 2011:116 and Webster \& Morley, 1997:1129). It is important to note that from a legal point of view, no distinction or reference is made to whether a brand is recognised or unrecognised from a financial accounting perspective. From a legal perspective these assets are all treated in the same manner, irrespective of origin as far as the accounting treatment is concerned.

From this section it can be concluded that brands are uncontested lifelines of many companies: they are used by companies to allow them to remain competitive and sustainable in the short and long run. Consequently, users of financial statements may find available information about these assets as indispensable to inform their decisions.

The next section identifies and discusses IAS38's disclosure requirements that are applicable to recognised intangible assets. 


\section{IAS38's DISCLOSURE REPUIREMENTS APPLICABLE TO RECOGNISED INTANGIBLE ASSETS}

IAS38's disclosure requirements are grouped and summarised under the following headings to guide the identification and subsequent evaluation of disclosure requirements:

- The economic lives of, and depreciation methods for intangible assets;

- Details regarding the carrying amounts (and changes to these) of intangible assets; and

- Details regarding encumbered intangible assets.

\subsection{Economic lives of, and depreciation methods for intangible assets}

IAS38 paragraph (a) states that an entity shall disclose 'whether the useful lives are indefinite or finite and, if finite, the useful lives or the amortisation rates used', while paragraph IAS38 (b) states that an entity shall also disclose 'the amortisation methods used for intangible assets with finite useful lives' (IASB, 2014). Pertaining to unrecognised internally generated brand assets, users of financial statements may incorrectly assume that brands have infinite or finite lives, when such information is not disclosed for unrecognised brands. Consequently it may be very difficult for users of financial statements to extrapolate current financial information into useful cash flow projections, when the necessary information concerning an asset's expected remaining useful lifetime is unavailable. Correia, Flynn, Uliana and Wormald (2013:6-21) point out that most monetary valuations of companies' equity are performed based on projections or estimates of future net cash flows.

A comparison with the IASB's objectives for financial statements as espoused in the Conceptual Framework for Accounting seems to present a conflict in this regard (IASB, 2014:A19-A20, paragraphs $O B 3$ and $O B 7$ ). Failing to disclose whether an unrecognised brand name has a finite or infinite economic lifetime may impede the decision-making ability of users of financial statements to make correct assumptions or forecasts regarding the amount of and extent of expected future cash flows. For instance, users of financial statements may incorrectly assume that the current income level as disclosed on the Statement of Comprehensive Income will continue indefinitely, when this may in fact not be the case. For companies that have a significant number of unrecognised brands, the impact of an erroneous assumption of this nature may be significant. As a result it may be concluded that the accounting standard fails to provide users of financial statements with the useful information in this regard. Adequate information, which is not provided, will allow them to make good decisions as envisaged by paragraph OBI (IASB, 2014).

The next section discusses the details regarding the carrying amounts (and changes to these) of intangible assets.

\subsection{Details regarding the carrying amounts (and changes to these) of intangible assets}

IAS38, paragraph 118 (e), requires the preparation and disclosure of a comprehensive reconciliation between the opening and closing balances of intangible assets (IASB, 2014). The reconciling items provide valuable information content to users of financial statements. It enables them to understand how an organisation's intangible asset base has changed since the 
previous SFP, or imminent changes in the near future. The reconciliation comprises the following three components:

- Additions to the asset class;

- Assets sold or reclassified in terms of IFRS 5 (assets held for sale); and

- Impairment losses incurred or reversed in the period.

\subsubsection{Additions to the asset class}

Disclosure of the amount of new additions (subsequent to successful internal development activities) to the intangible asset base is also required in this reconciliation. If the recognition of internally generated brands is prohibited, it follows that the information would not be disclosed here, and this seems to be in stark contrast with the case of an acquired brand. Theoretically, then, as a result of the existing requirements of IAS38, users of financial statements may be unaware of the existence of internally generated brands, except to the extent that the preparers of financial statements opt to disclose such information voluntarily, or make this information available using alternative channels.

As and when a newly generated brand starts to generate income, this income is aggregated together with all the other revenue streams produced by the other assets in a company. This aggregated amount is then disclosed as a single amount, called revenue, on the face of the Statement of Comprehensive Income. Arguably, this aggregated amount seems useful only insofar as the amount reported as revenue can be compared to the asset base which produced the reported income. This comparison may have been useful to users of financial statements to evaluate management's stewardship over assets. However, such comparison may under current accounting standards be distorted, because total assets from the SFP would be understated due to the non-recognition of internally generated brands. The situation seems untenable - informing users about the fruit, but nothing about the tree.

It would not seem as if users of financial statements have access to knowledge regarding the existence of internally developed brands, while at the same time it has been shown that a situation like this significantly impedes the IASB's objective of enabling users to make informed decisions.

\subsubsection{Assets sold or reclassified in terms of IFRS $\mathbf{5}$ (assets held for sale)}

As opposed to recognised brands, management of an organisation is under no obligation to disclose its intention to sell an unrecognised brand in the near future (IASB, 2014). For valuation purposes, outstanding information of this nature may render an attempt to perform an accurate equity valuation inaccurate or incomplete. To perform a cash-based valuation, users of financial statements would need information enabling them to project or forecast future cash flows. Not finding any information disclosed in the financial statements concerning management's possible intention to sell a cash-generating, yet unrecognised, asset, may result in users of financial statements making incorrect assumptions. This may be the result if reported income for the current financial year is merely extrapolated unadjusted without reflecting the cash flow effects resulting from the future absence of the unrecognised brand asset.

This may present a severe failure in fulfilling the espoused objectives of the IASB regarding the overarching purpose of financial statements. One might argue that the message regarding the imminent sale of an unrecognised brand may be covered by the onerous disclosure requirements 
contained in paragraph 33 of IFRS 5 (IASB, 2014). This disclosure is mandatory for entities that have a discontinued operation at year end (IASB, 2014). However, brands are often sold alone, leaving the rest of operations intact and operating in much the same way as before (Watson, 2012:17). In such circumstances the required disclosure as part of a discontinued operation would not render any useful information regarding the sale of an unrecognised brand, as it would not necessarily form part of a discontinued operation. Furthermore, the sale of brands has significant signal-effects regarding a company's operational performance and the adequacy of brand portfolio management that consequently informs stock prices (Wiles, Morgan \& Rego, 2012; John \& Ofek, 1995 and Lang, Poulsen \& Stulz, 1995). This clearly proves the point that investors find information about such events useful. In a similar vein, selling an asset may change the risk profile of the entire business, making a firm almost twice as likely to be taken over, something which ought to be taken into account in the determination of an appropriate discount rate for subsequent use in valuations (Hanson \& Song, 2006). Failure by those preparing valuations to appropriately incorporate and make adjustments to changes in a company's risk profile that have a bearing on estimated future cash flows may result in an inappropriate equity valuation and, consequently, inappropriate decisions made by users of financial statements.

Having clearly argued the importance and relevance of information regarding the sale of assets, it would in fact seem as if the Conceptual Framework of Accounting's overall objective with financial statements - that is, to provide users of financial statements with useful information may not be met. This is so particularly with regard to the availability of relevant information that may affect an entity's future cash flows, which is omitted.

\subsubsection{Impairment losses incurred or reversed in the period}

Although unrecognised internally generated brands may never be subjected to an impairment test performed under the guidance of IAS36 Impairment of Assets, it seems logical that these unrecognised assets may nevertheless also become impaired. However, given these assets' unrecognised status, it seems unlikely that users of financial statements would ever be informed of the occurrence of such an event.

Research suggests that investors find information regarding the impairment of assets useful (Hirschey \& Richardson, 2003; AbuGhazaleh, Al-Hares \& Haddad, 2011 and Bens \& Heltzer, 2011). It seems hardly conceivable that the same usefulness may not also be attributable and indeed relevant to unrecognised internally generated brands. If users of financial statements had been informed of the impaired status of an unrecognised asset, it seems plausible that such information might have been used to adjust the future amount of cash flows expected to accrue to the entity. Failure to do so may result in inaccurate valuations, which seems to be in conflict with the Conceptual Framework for Accounting's objectives in paragraph OB3 (IASB, 2014:A19).

One may argue that unrecognised brands may form part of a cash-generating unit which may have been subjected to an impairment test and of which disclosure would as a result be available in terms of IAS36, paragraph 130 (IASB, 2014). However, any necessary impairment that results from a cash-generating unit would only be allocated amongst other recognised assets (such as property, plant and equipment and goodwill) according to IAS36 paragraph C5 (IASB, 2014). The possible implication is that users of financial statements may not have adequate information to evaluate management's stewardship with regard to the utilisation of these valuable incomegenerating assets. This seems to present a conflict with regard to the stated objective contained in paragraph OB4 of the Conceptual Framework for Accounting, which seeks to provide users of 
financial statements with the information they need to assess how efficiently management has used an entity's resources.

The next section discusses details about encumbered intangible assets.

\subsection{Details regarding encumbered intangible assets}

IAS38, paragraph 122 (d), states that an entity shall disclose 'the existence and carrying amounts of intangible assets whose title is restricted and the carrying amounts of intangible assets pledged as security for liabilities' (IASB, 2014). With reference to the information contained in paragraph $122(d)$, users of financial statements may remain unaware of any restrictions or encumbrances with legal backing on the title of an unrecognised, yet proprietary owned, brand name. Failing to communicate such a fact to investors or shareholders may mislead them in their decision-making processes. Users of financial statements may end up making inappropriate judgements regarding the financial risk that a company is subjected to. An unrecognised brand may present one of an entity's core cash-generating assets, in which case knowledge of any pledges as collateral for debt may sway decisions regarding investors' willingness to invest in or lenders lending to the company.

Ford Motor Company reported that it had arranged a credit line to the value of $\$ 8 \mathrm{bn}$ in 2006, mentioning putting up 'some' of its brands as collateral for the debt (Koenig, 2006:22). Ford Motor Corporation's 2006 financial statements only disclosed the fact that certain brands were pledged for credit facilities, and failed to indicate distinctly which brands were pledged or whether these brands were recognised or unrecognised intangible assets (Ford Motor Company, 2007:73). The financial statements for 2007 disclosed nothing more, so arguably leaving users of financial statements in the dark as to the level of risk exposure involved (Ford Motor Company, 2008:83).

It is posited that this information may be significant in influencing the investment decisions of users of financial statements. It seems evident that the Ford Motor Corporation's overall risk profile would have been significantly changed for the worse, had it been the Ford brand that was put up as collateral. The fact would have been severely exacerbated if this had not been communicated to users in the financial statements (disclosure that is currently not required), had the Ford brand been an internally generated brand under the existing IAS38. It seems clear that, had this been the case, such information, if disclosed, could very well have influenced investors' decisions with regard to investment decisions in such a company.

The next section discusses the IASB's specific encouragement in IAS38 to reporting entities to disclose voluntarily information as part of financial statements about assets which cannot be recognised as assets in the SFP. It also assesses whether such encouragement may in fact relieve the paucity of available information for these assets.

\section{VOLUNTARY DISCLOSURE OF INFORMATION ABOUT NON-RECOGNISED ASSETS}

IAS38 does not ignore users' information needs pertaining to unrecognised intangible assets entirely. IAS38, paragraph 128(b), encourages

disclosures of a brief description of significant intangible assets controlled by the entity but not recognised as assets because they did not meet the recognition criteria in this Standard (IASB, 2014). 
The complex situation presented by the non-recognition of internally generated brands may have been tenable had companies freely and frequently opted to disclose information regarding these assets as encouraged. However, an analysis of the disclosure pertaining to intangible assets with a specific focus on the brands on all five companies listed on the Johannesburg Stock Exchange's food and beverage sector refutes such a notion (these five companies are: Clover, Distell, Pioneer Foods, SABMiller plc and Tiger Brands). Although all these brand-rich companies duly disclosed the necessary information in compliance with the IAS38's requirements applicable to them, not one of them made any reference to the existence or nature, of any unrecognised intangible brand assets, nor to any other category of intangible asset except for goodwill, where applicable (Clover, 2013:134; Distell, 2013:87; Pioneer Foods, 2013:151-154; SABMiller, 2014:121 and Tiger Brands, 2013:175-177). It seems almost inconceivable that none of these companies, despite the small sample, owned at least one significant internally generated unrecognised brand asset that they could disclose voluntarily.

Although the selection of companies used in this limited investigation is small and perhaps not statistically valid for extrapolation to other companies, it may suggest that any hopes placed on voluntary disclosure, as encouraged to complement or consummate the provision of useful information to users of financial statements, may in fact be entirely misplaced. There are plausible reasons for the reluctance to disclose information voluntarily. Management may in fact not be inclined to disclose information voluntarily, as by doing so it could elicit closer scrutiny by users of financial statements and ultimately impugn adequate asset management. Kothari, Shu and Wysocki (2008:273) found that managers often delay communicating unfavourable news to shareholders. Such delay may be exacerbated where such communication is only voluntarily required, as may also be the case with unrecognised brand assets and unfavourable news in this regard. Consequently, it would not seem as if the encouragement to disclose information voluntarily will ameliorate the paucity of information regarding internally generated brands.

\section{CONCLUSION}

Internally generated brands, despite their significant economic values and strategic importance, are not recognised as assets in terms of the current IAS38. This article identified several important facts about internally generated brands which are not disclosable. As opposed to the comprehensive disclosure requirements that are imposed on and pertain to recognised brands, users of financial statements are not informed about the existence of internally generated brands, nor about management's intention to sell such brands in the near future, and also not about impairments in the value of these assets.

Furthermore, the article highlighted that financial statements do not have to inform users about instances where unrecognised brands were pledged as security for debt to third-party credit providers. The article also argued that such undisclosed information may compromise the usefulness of financial statements. If users of financial statements contrive to value companies, but fail to incorporate undisclosed information about unrecognised brands into valuation models, the end result may well be erroneous or unsuitable to its purpose.

Returning to the quote by De Saint-Exupéry (2009) in the introduction, it may be concluded that what seems essential to know about internally generated brand assets may be well-nigh invisible to the eyes of the users of financial statements. 


\section{RECOMMENDATIONS}

The following recommendations may prove to be relevant to compilers of financial statements as well as to the IASB or other accounting standard bodies in the development or amendments of future standards on intangible assets. Furthermore, it may also provoke stakeholders to take a renewed interest in and encourage more emphasis on the useful contribution that information contained in the note-disclosure may make as part of endeavours to provide users of financial statements with useful information as espoused in the Conceptual Framework of Accounting. The recommendations do not seek to enter the debate concerning the merits or demerits of the recognition of previously unrecognised intangible assets through amendments to existing asset recognition criteria. Although so-called 'fair value accounting' is probably slowly making its appearance in the accounting domain, it is the contention of this article that the concerns indicated in the findings above may be mitigated through some practical steps. It mainly seeks to improve note-disclosure regarding unrecognised brand assets in the following four main respects:

Firstly, IAS38 paragraph 128, which communicates the existence of significant unrecognised intangible assets, may well be amended to impose mandatory note-disclosure concerning all such significant unrecognised brand assets.

Secondly, in addition to the first recommendation, which will improve communication regarding the existence of unrecognised brand assets in companies, it may be useful if the operating segments in which such unrecognised brands are used are clearly identified. This would enable users of financial statements to form a better opinion of the impact that such a brand has on the results of a specific segment. The impact of a sale or the intention to sell an unrecognised brand asset may also be better understood or determinable, as the income and cash flow streams would be identifiable. This may arguably also enable users of financial statements to better assess, through a year-by-year comparison, the impact of a brand's existence on performance. It may also enhance decision-makers' ability to place a value on brands, although it will not do this to the fullest possible extent.

Thirdly, it is suggested that the disclosure requirements regarding the existence of legal restrictions (contained in IAS38, paragraph (d)) on the title of recognised intangible assets should be extended to be imposed on unrecognised brands as well. This is because a restriction on the owner's title imposes the same risk to the general risk profile of a company as a recognised intangible asset does. Users of financial statements ought to know whether the legal ownership or title for any resource currently generating income has been restricted, irrespective of the accounting treatment thereof.

Finally, it is recommended that management's intention to sell any unrecognised asset, such as a brand, be communicated to users of financial statements in note-disclosure as envisaged by IFRS 5. This may be even more important if such an unrecognised brand generates a significant portion of a company's income.

\section{LIST OF REFERENCES}

Aaker, D. (2004). Brand Portfolio Strategy. New York: Free Press.

AbuGhazaleh, N.M., Al-Hares, 0. \& Haddad, A.E. (2012). The Value Relevance of goodwill impairments: UK Evidence. International Journal of Economics and Finance, 4(4):206-216. 
Appuhami, B.A.R. (2007). The impact of intellectual capital on investors' capital gains on shares: An empirical investigation on Thai Banking, Finance and Insurance Sector. International Management Review, 3(2):14-25.

Barth, E., Clement, B., Foster, G. \& Kasznik, R. (1998). Brand Values and Capital Market Valuation. Review of Accounting Studies, 3:41-68.

Barth, M. \& Clinch, G. (1998). Revalued Financial, Tangible, and Intangible Assets: Associations with Share Prices and Non-Market-Based Value Estimates. Journal of Accounting Research, 36(Supplement):199-233.

Bens, A.D., Heltzer, W. \& Segal, B. (2011). The Information Content of Goodwill Impairments and SFAS 142. Journal of Accounting, Auditing and Finance, 26(3):527-555.

Chalmers, K., Clinch, G. \& Godfrey, J.M. (2008). Adoption of International Financial Reporting Standards: Impact on the Value Relevance of Intangible Assets. Australian Accounting Review, 46(18):237-247.

Clover. (2013). Integrated Report. Available: http://www.clover.co.za/annual-report. (Accessed 17 July 2014).

Correia, C., Flynn, D., Uliana, \&. \& Wormald, M. (2013). Financial Management. Cape Town: Juta.

Crimmins, C. (2000). Better measurement and management of brand value. Journal of Advertising Research, 40(6):136-144.

De Saint-Exupéry, A. (2009). The little prince. London: Egmont UK Limited.

Distell. (2013). Integrated Annual Report. Available:

http://www.distell.co.za/Runtime/POPContentRun.aspx?PagelDRef=2573. (Accessed 17 July 2014).

The Economist. (2014). What are brands for? Available:

http://www.economist.com/news/business/21614150-brands-are-most-valuable-assets-manycompanies-possess-no-one-agrees-how-much-they. (Accessed 30 July 2015).

Ford Motor Company. (2007). Financial Report 2006. Available:

http://ophelia.sdsu.edu:8080/ford/12-30-2012/our-company/investors/reports-financialinformation/annual-reports.html. (Accessed 30 July 2015).

Ford Motor Company. (2008). Financial Report 2007. Available:

http://ophelia.sdsu.edu:8080/ford/12-30-2012/our-company/investors/reports-financialinformation/annual-reports.html. (Accessed 30 July 2015).

Fraser, I., Tarbert, H. \& Hong-Tee, K. (2009). Do the financial statements of intangible-intensive companies hold less information content for investors? Applied Financial Economics, 19:1433-1438.

Hanson, R.C. \& Song, M.H. (2006). Corporate Governance and Asset Sales: The Effect of Internal and External Control Mechanisms. The Financial Review, 41:361-386.

Hirschey, M. \& Richardson, V.J. (2003). Investor under reaction to goodwill write-offs. Financial Analysts Journal, 59(6):75-84.

Hutchinson, T. \& Duncan, N. (2012). Defining and describing what we do: Doctrinal legal research. Deakin Law Review, 17(1):83-119.

IASB. (2014). International Accounting Standards Board. A Guide through International Financial Reporting Standards. London: IFRS Foundation Publications Department.

John, K. \& Ofek, દ. (1995). Asset sales and increase in focus. Journal of Economics, 37:105-126. 
Klopper, H.B., Pistorius, T., Rutherford, B.R., Tong, L., Van der Merwe, A. \& Van der Spuy, P.d W. (2011). Law of Intellectual Property in South Africa. Durban: LexisNexis.

Koenig, B. (2006). Ford to back $\$ 18$ billion in new loans with assets. Bloomberg News, as reported in the International Herald Tribune, November 28.

Kohlbeck, M. \& Warfield, D. (2007). Unrecorded Intangible Assets: Abnormal Earnings and Valuation. Accounting Horizons, 21(1):23-41.

Kothari, S.P., Shu, S. \& Wysocki, P.D. (2008). Do Managers Withhold Bad News? Journal of Accounting Research, 47(1):241-276.

Lang, L., Poulsen, A. \& Stulz, R. (1995). Asset sales, firm performance, and the agency costs of managerial discretion. Journal of Financial Economics, 37:3-37.

Lev, B. (2003). Remarks on the measurement, valuation, and reporting of intangible assets. Federal Reserve Bank of New York: Economy Policy Review, (September):17-22.

Mizik, N. \& Jacobson, R. (2008). The Financial Value Impact of Perceptual Brand Attributes. Journal of Marketing Research, XLV: 15-32.

Mizik, N. \& Jacobson, R. (2009). Valuing Branded Businesses. Journal of Marketing, 73 (November):137-153.

Morgan, N.A. \& Rego, L.L. (2009). Brand Portfolio Strategy and Firm Performance. Journa/ of Marketing, 73:59-74.

Petty, R. \& Guthrie, J. (2000). Intellectual capital literature review - Measurement, reporting and management. Journal of Intellectual Capital, 1(2):155-176.

Pioneer Foods. (2013). Integrated Report. Available:

http://www.pioneerfoods.co.za/investors/financial-results-archive/. (Accessed 17 July 2014).

Powell, S. (2003). Accounting for intangible assets: current requirements, key players and future directions. European Accounting Review, 12(4):797-811.

SABMiller (2014). Annual Report, 2014. Available: http://www.sabmiller.com/investors/reports. (Accessed 17 July 2014).

Sinclair, R.N. \& Keller, K.L. (2014). A case for brands as assets: Acquired and internally developed. Journal of Brand Management, 21(4):286-302.

Strauss, C. \& Willemse, L. (2014). A critical investigation of the interaction between Sections 8(4)(A), $9(\mathrm{H})$ and Paragraph 40 of the Eighth Schedule of the Income Tax Act No.58 of 162 versus the current practise of the South African Revenue Service. Journal of Economic and Financial Sciences, 7(3):887902.

Swartz, G.E. \& Swartz, N.P. (1995). An empirical examination of the value relevance of intellectual capital using the Ohlson valuation model. Meditari Accountancy Research, 14(2):67-81.

Tiger Brands. (2013). Integrated Annual Report. Available: http://www.tigerbrands.co.za/invest.php (Accessed 17 July 2014).

Tollington, T. (1998). Brands: the asset definition and recognition test. The Journal of Product and Brand Management, 7(3):180-192.

Watson, W. (2012). Tiger Brands koop ikoniese Mrs Ball's vir R475m. Sake-Beeld, 10 December: 17. 


\section{Van der Spuy}

Webster, C.E. \& Morley, G.E. (1997). Webster and Page South African Law of Brands. Durban: LexisNexis.

Wiles, M.A., Morgan, N.A. \& Rego, L.L. (2012). The Effect of Brand Acquisition and Disposal of Stock Returns. Journal of Marketing, 76:38-58.

Wyatt, A. (2002). Towards a financial reporting framework for intangibles. Journal of Intellectual Capital, 3(1):71-86.

Wyatt, A. \& Abernethy, M. (2008). Accounting for Intangible Investments. Australian Accounting Review, 18(2):95-107. 